\title{
Good outcome of AIDS-related Burkitt lymphoma (BL) and diffuse large B-cell lymphoma (DLBCL) with abbreviated cycles of EPOCH-rituximab
}

\author{
K Dunleavy*, RF Little, AS Wayne, N Grant, S Pittaluga, ES Jaffe, S Steinberg, \\ R Yarchoan, J Carrasquillo, J Janik and WH Wilson
}

Address: Center for Cancer Research, National Cancer Institute, Bethesda, Maryland, USA

* Corresponding author

\author{
from I I th International Conference on Malignancies in AIDS and Other Acquired Immunodeficiencies (ICMAOI): Basic, Epidemiologic, and Clinical \\ Research \\ Bethesda, MD, USA. 6-7 October 2008 \\ Published: 17 June 2009 \\ Infectious Agents and Cancer 2009, 4(Suppl 2):O9 doi:10.1 I86/I750-9378-4-S2-O9
}

This abstract is available from: http://www.infectagentscancer.com/content/4/S2/O9

(c) 2009 Dunleavy et al; licensee BioMed Central Ltd.

The addition of rituximab to CHOP chemotherapy may augment tumor response but in patients with low CD4 counts, one study suggested that this benefit may be offset by increased infectious deaths (Kaplan. Blood 2005; 106:1538). We hypothesized that the addition of rituximab to EPOCH chemotherapy could improve tumor kill, allowing fewer cycles of treatment and therefore reducing toxicity.

Patients received EPOCH-R (in $\mathrm{mg} / \mathrm{m}^{2} / \mathrm{d}$ - etoposide 50 , vincristine 0.4 and doxorubicin 10 all CIV d 1-5; cyclophosphamide $750 \mathrm{mg}$ IV d 5; prednisone 60 po days $1-5$ and rituximab 375 IV d 1,5 and G-CSF sc d 6-15) every 21 days. Prophlactic IT methotrexate was administered and HAART was suspended during therapy. Cyclophosphamide was adjusted based on absolute neutrophil count (ANC) nadir. Response was assessed by CT and FDG-PET scan and patients received one cycle beyond CR for a minimum of three cycles. Characteristics of 40 enrolled patients are: median (range) age 42 (9-60) years; IPI 3 (04); ECOG PS 1 (1-4), CD 4 count $222(0-835)$ cells $/ \mathrm{mm}^{3}$; HIV viral load 34,766 (0-6,080000) RNA copies $/ \mathrm{mL}$; male sex 35 (88\%); LDH > N 27 (68\%); stage IV 27 (68\%) and histology DLBCL $32(80 \%)$ and BL 8 (20\%). Of 38 evaluable patients (2NE), median (range) number of cycles given is three (3-5) with CR/CRu in $35(92 \%)$ and $\mathrm{PR}$ in one $(3 \%)$ patients.
All eight patients with Burkitt lymphoma are in continuous remission. At four years median potential follow-up, PFS and OS are 86 percent and 70 percent. For patients with CD4 $>$ and $<100$ cells $/ \mathrm{mm}^{3}$ PFS is 96 percent and 69 percent, respectively. IPI did not impact OS and PFS. Early PET scanning (after cycle 2) had a very high negative predictive value $(100 \%)$ but a low positive predictive value $(20 \%)$. One treatment-related death occurred (from complications of mycobacterium avium intercellulare (MAI)) and other toxicity included fever or neutropenia on 30 percent, ANC $<500 / \mathrm{mm}^{3}$ on 40 percent, and platelets < 50,000 on 23 percent cycles. EPOCH-R was associated with less CD4 loss - median 128 cells $/ \mathrm{mm}^{3}$ (range +154 to -639) compared to EPOCH alone (median 189 cells/ $\mathrm{mm}^{3}$ (range +19 to -973 ). Abbreviated EPOCH-R is highly effective with acceptable tolerability in ARL and enables the administration of fewer treatment cycles (median 3 versus 6). Although patients with $\mathrm{CD} 4<100 / \mathrm{mm}^{3}$ have good tumor control with EPOCH-R with a PFS of 70 percent at four years, overall survival for this group was only 31 percent due mainly to later deaths from complications of advanced AIDS. In contrast, patients with high CD4 counts $>100 / \mathrm{mm}^{3}$ have an extremely favorable outcome with and survival following EPOCH-R. The addition of rituximab did not appear to contribute to infection related complications or deaths. EPOCH-R showed excellent efficacy in eight patients with BL with an OS and PFS of 100 percent. PET scanning has a high negative but low positive 
predictive value for subsequent relapse. Accrual continues.

Publish with Biomed Central and every scientist can read your work free of charge

"BioMed Central will be the most significant development for disseminating the results of biomedical research in our lifetime. " Sir Paul Nurse, Cancer Research UK

Your research papers will be:

- available free of charge to the entire biomedical community

- peer reviewed and published immediately upon acceptance

- cited in PubMed and archived on PubMed Central

- yours - you keep the copyright

Submit your manuscript here:

http://www.biomedcentral.com/info/publishing_adv.asp 